\title{
The Impact of Financial Instruments of the Foreign Exchange Market on Capital Migration in Kazakhstan
}

\author{
Olga Valentinovna Koshkina ${ }^{1}$ Natalya Valentinovna Koshkina ${ }^{2} \&$ Rafael Envarovich Abdulov ${ }^{3}$ \\ ${ }^{1}$ University of International Business, Kazakhstan \\ 2 “Almaty Management University” NEI, Rozybakiev str, 227, Almaty, Kazakhstan \\ ${ }^{3}$ National Research Nuclear University MEPhI, Russia \\ Correspondence: Olga Valentinovna Koshkina, University of International Business, Abay, 8a, Almaty, 050010, \\ Kazakhstan.
}

Received: December 30, 2014 Accepted: February 27, 2015 Online Published: May 22, 2015

doi:10.5539/ass.v11n14p10 URL: http://dx.doi.org/10.5539/ass.v11n14p10

\begin{abstract}
The capital migration is one of the important economic processes in a state. There many reasons for the capital exports and imports: the investment climate in a country, the changing rate of profit, labor, raw materials, environmental standards, etc. In the circumstances of global financial crises, which unveil the dependence of countries, the analysis of capital flows is an essential issue. The result of this analysis is the development of anti-migration measures. This article deals with the influence of financial instruments of the foreign exchange market on the migration of capital in the Republic of Kazakhstan. To date, the majority of transactions are conducted on the foreign exchange market of Kazakhstan, which gives reason to make assumptions about the impact of the foreign exchange market on the capital flows in Kazakhstan. The article provides statistical data for the period from 2007 to 2013, a regression analysis, conclusions, and recommendations. The resulting coefficient of determination at $96 \%$ confirms the impact of money market instruments on the capital migration in Kazakhstan. Based on the calculated model, we can conclude on the strong interrelation between capital flows and indicators such as the volume of transactions by resident banks, net operations by exchange offices (Foreign exchange cash), imports/exports of the foreign exchange cash by second-tier banks, the trading volume on the Kazakhstan Stock Exchange.
\end{abstract}

Keywords: capital migration, foreign exchange market, private capital flow, exchange rate, exchange trading

\section{Introduction}

The international capital flow holds a leading position in international economic relations and has a huge impact on the global economy.

The specificity of Kazakhstan at the present stage is the combination of a developed and developing country. On the one hand, it is the overall literacy of the population, an extensive network of research institutions, and space research. On the other hand, the raw material orientation of the economy, the environmental pollution in many regions, the need for foreign investment and import of new technologies, the infrastructure backlog. Nevertheless, Kazakhstan has positive expectations for the future: it expects a strong increase in exports and external surplus, GDP growth, reduction of unemployment, and convertibility of the national currency.

State programs of development of the monetary and foreign exchange sectors of Kazakhstan clearly demonstrate the intention of the leading public financial and monetary authorities to pursue a policy of strengthening the position of Kazakhstan on the world financial and foreign exchange market and complete the process of Kazakhstan integration into the world economy.

Disproportionate offer of and demand for capital in the various parts of the global economy, the growing interdependence of national economies, and the internationalization of production have been the drivers and catalysts of the capital floating in the regional and national scale. Exports and allocation of capital in certain countries with the purpose of its accumulation is an integral part of TNCs' activities, when investment in the subsidiaries by their parent companies is an important argument for expanding the geography of production and marketing of their products. Thus, according to expert estimates, there are about USD400 billion of free capital in the modern global economy ( $80 \%$ of which belongs to TNCs), which, erasing national borders of countries, 
move in the direction of the markets that are prospective in terms of profitability and in highly profitable industrial complexes. The vector of their direction is largely determined by the current political and economic situation in the country and the region, as well as the created favorable conditions for investors.

The following sources of operating efficiency of TNCs in the field of capital migration are considered the main ones:

- the use of the advantages of owning natural resources (or access to them), capital, and knowledge, especially the $R \& D$ results, compared to domestic firms;

- the opportunity of choosing the optimal location for their businesses in different countries, taking into account the size of their domestic markets, the economic growth rate, the price and skills of manpower, the prices and availability of other economic resources, the infrastructure development status, as well as political and legal factors;

- the opportunity of accumulating capital throughout the system of TNCs, including borrowed funds in the countries where their foreign affiliates are located, and application of the capital in the most favorable circumstances and locations for the companies;

- the use of the financial resources of the whole world for their own purposes;

- continuous awareness of the state of the commodity, currency, and financial markets in different countries, which allows quickly transferring capital flows to those states where the conditions allow for maximum profit gain, and at the same time allocate financial resources with minimal risks (including risks of national currencies fluctuations);

- rational organizational structure, which is constantly being improved;

- experience in international management, including optimal organization of production and marketing, maintaining the high reputation of the country.

In the circumstances of the global financial crises, when the dependence of countries manifests itself, the analysis of capital flows is an essential issue. The result of this analysis is the development of anti-migration measures. The issue of influence of the money market instruments on the process of capital flows in Kazakhstan in this regard requires an analysis. The foreign exchange market is represented here not by chance, since currently most transactions are conducted in Kazakhstan on this market.

Many publications have focused on the problems of movement of capital and the money market instruments. At the present stage, the publications by the following authors have been the most interesting in the study of the above named research: Loskutov, V. I. (2000); Borishpolets, K., Chernyakovskiy, S. (2012); Kurmanalieva, E. S., Vinokurov, E. Y. (2011); Plekhanov, D. A. (2009);Bernshtam, B. E. (2013); Dobychin, E. V. (2003); Iskakov, U. M., Ruzieva, E. A. (2014); Sophie Brana, Delphine Lahet (2010); Eduardo Levy Yeyati, Sergio L. Schmukler, Neeltje Van Horen (2009); Jonathan D. Ostry, Atish R. Ghosh, Marcos Chamon, Mahvash S. Qureshi (2012); Peter D. Richards, Robert J. Myers, Scott M. Swinton, Robert T. Walker (2012); Eliana A. Cardoso, Rudiger Dornbusch (1989); Можно убрать?; Khuhawar Khizer Hayat, Zeng Jianqiu (2013); Rasha Al-Sakka, Owain ap Gwilym (2010); Gisela P. Zapata (2013) ; Odongo Kodongo, Kalu Ojah (2013); Ozan Sula, Thomas D. Willett (2009).

The presented studies do not consider the Kazakhstan market, so it is necessary to study in more detail the reasons for capital migration in Kazakhstan.

The purpose of this study was to analyze the influence of money market instruments on capital flows in the Republic of Kazakhstan, based on the statistics and regression analysis, providing conclusions and recommendations on the considered issue.

\section{Methodology}

To determine the influence of money market instruments on the capital migration, we used the regression analysis technique. With this purpose, we collected statistics on the inflow/outflow of capital in Kazakhstan from 2007 to 2013 and determined the possible factors of influence of the money market instruments on the migration processes in Kazakhstan.

\subsection{Capital Migration and the State of the External Debt in Kazakhstan}

Capital migration is a process when capital leaves the economy of one country in order to earn higher income in another. A study of the impact of migration of capital is relevant because the rapid growth in recent decades in the international trade, international interbank loans, intergovernmental loans and transactions on the stock and 
foreign exchange markets of various countries has been accompanied by the rapid development of the international capital market. The international movement of capital has a huge impact on the global economy. It manifests itself primarily in the fact that the international transfer of capital contributes to the global economic growth. This is due to the fact that a country having sufficient capital or capital goods can establish production abroad through investments and gain a greater economic benefit than in the result of foreign trade. It is determined by the fact that the country receiving capital may have cheaper labor, raw materials, or more favorable investment climate, such as availability of free economic zones or low environmental standards.

One of the characteristic phenomena of the modern global economy is the scaling-up of the capital migration between countries. International capital market is an important part of the economy, ensuring the movement of financial resources. Moving the production factors from countries excessively endowed with relatively inexpensive production factors to countries where they are relatively scarce and expensive results in equalizing the prices for the production factors, that is, in improvement of the welfare of the countries participating in this exchange.

Capital migration in Kazakhstan is represented by the following data. During the period from 2007 to 2013, capital inflow was observed in Kazakhstan. During the period from 2007 to 2008, the inflow reduced significantly, reaching USD 2,384 million. During the following two years, there was a tendency to reduction of the capital import. In 2010, the imports of capital amounted to USD 1,269 million. In 2013, the imports of capital amounted to USD 8,366 million. The dynamics is shown in Figure 1.

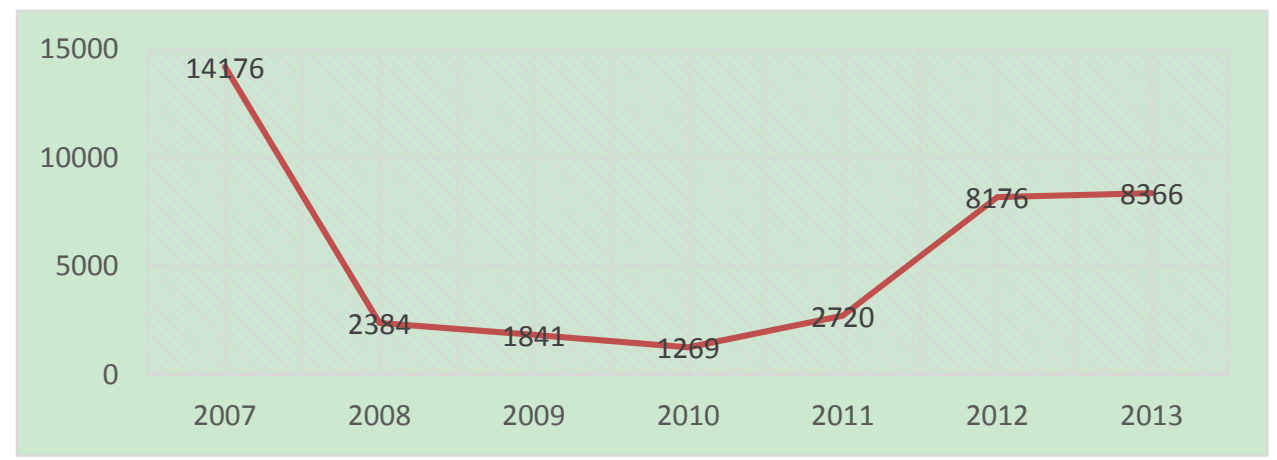

Figure 1. Net capital imports(+)/exports(-) in Kazakhstan, in million US dollars, according to (http://www.nationalbank.kz/)

\subsection{The External Debt of Kazakhstan}

Next, let us consider the state of the external debt of Kazakhstan. The following Figure 2 shows the downward trend in the external debt in 2010 and 2011, and then shows the growth of the external debt in 2012 and 2013. As of 2013, the external debt of Kazakhstan amounted to USD 6,156.6 million.

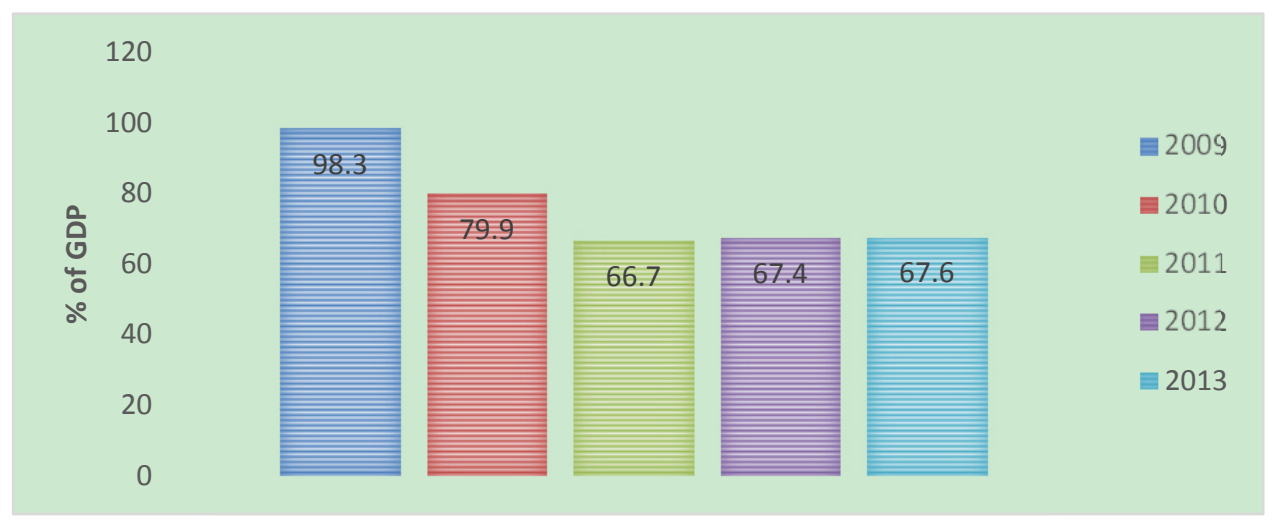

Figure 2. The external debt of Kazakhstan, \% of GDP (http://www.nationalbank.kz/) 
In terms of the economy sectors, a significant share of the external debt belongs to intercompany receivables and other sectors. By falling down to $72.7 \%$ and $59.2 \%$, accordingly in 2013 , banks during this period showed a decline in the share to $11.2 \%$, while the government authorities and the central bank increased their share in the foreign debt to $5.7 \%$.

"The increase in the external debt of the Government of the Republic of Kazakhstan mainly affects the inflow of funds in the state foreign loans, which amounted to USD 0.8 billion in 2013. Moreover, these funds were raised mainly to finance the construction of roads within the "Western Europe - Western China" project. With account of the maturity of existing external loans and foreign exchange differences in them, the foreign debt of the "public administration bodies" for the period increased by USD 0.3 billion. The external debt of the National Bank of Kazakhstan decreased by USD 73.0 million at the expense of commitments for correspondent accounts and deposits of non-residents in the National Bank of Kazakhstan (a decrease by USD 81.4 million) and exchange rate fluctuations (USD -137.5 million). The external debt of the sector in the absence of non-residents' transactions with short-term notes of the National Bank of the Republic of Kazakhstan remained stable over the last three years (about USD 0.6 billion)". (http://www.nationalbank.kz/)

\subsection{Gross Outflow and Inflow of Direct Investments and Openness of the Economy}

The gross outflow and inflow of direct investments in Kazakhstan is represented in the trend in both cases (Figure 3, 4)

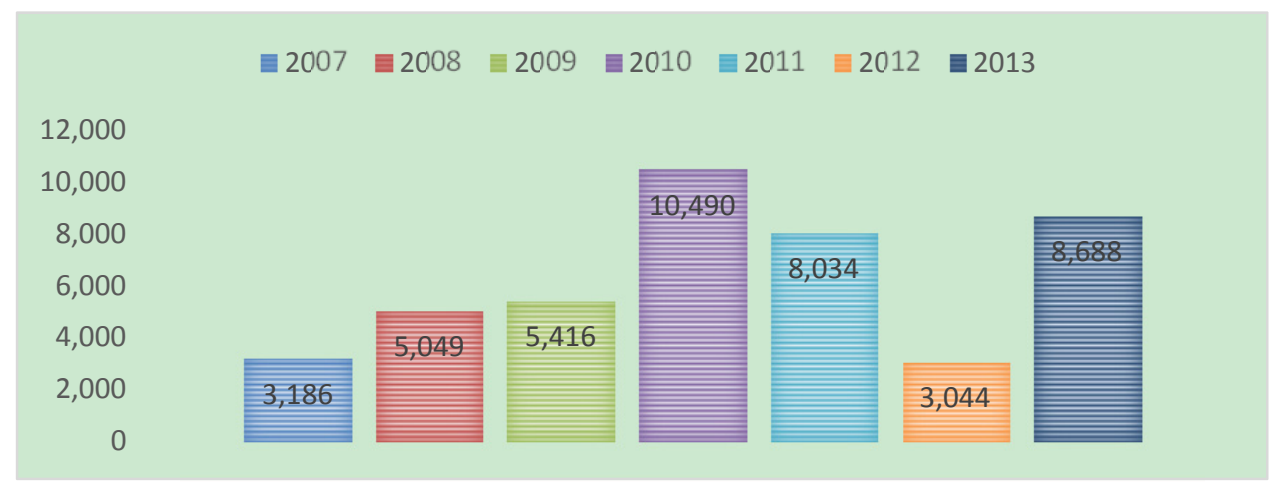

Figure 3. Gross outflow of direct investments in Kazakhstan, in million US Dollars (http://www.nationalbank.kz/)

Gross outflow of direct investments abroad from direct investors of Kazakhstan includes the increase of equity instruments, reinvested earnings, and the increase in debt instruments.

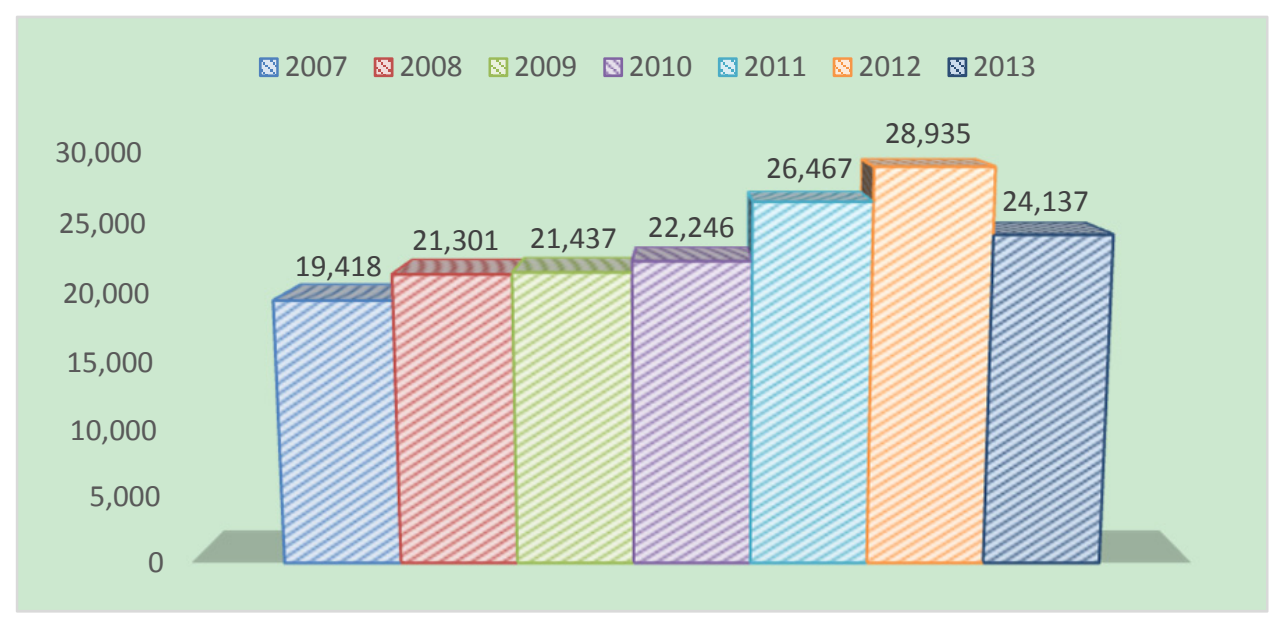

Figure 4. Gross inflow of direct investments in Kazakhstan, in million US Dollars (http://www.nationalbank.kz/) 
Despite the decline in comparison with 2010, the gross inflow of foreign direct investments to the republic remains at a high level - more than USD 24 billion for the year under review. "The reduction of the gross inflow is caused by the lack of large single transactions to acquire shares in the Kazakhstani capital, which was observed in 2012, as well as with the decrease in the volume of financing of the North-Caspian project"(http://www.nationalbank.kz/).

Taking into account the repayment of the principal debt under mutual intercompany liabilities, the net inflow of direct investments in Kazakhstan reached USD 10.2 billion, and the net outflow abroad - USD 2.4 billion.

One of the determining factors of the flows of both the long-term and short-term capital is the openness of the country. The indicator of an economy's openness, which is calculated as the ratio of turnover to the GDP has declined in the analyzed period by $5.6 \%$ to $59.7 \%$ with a decrease in the share of exports in GDP by $5 \%$, and the share of imports - by $0.6 \%$. Exports and imports in 2013 were at the level of 2009 , i.e. $37.5 \%$ and $22.2 \%$ respectively.

\subsection{Factors of the Foreign Exchange Market Affecting the Capital Migration in Kazakhstan}

The development of the Kazakhstan's foreign exchange market is determined by the impact of two main factors - firstly, the liberalization of foreign exchange transactions and increase in the degree of openness of national markets, and secondly, introduction of new foreign exchange and financial instruments and modern technologies in the foreign exchange market. The foreign exchange markets of developing countries and countries with economies in transition are currently at the stage of liberalization, which gives a great opportunity to strengthen further the role of the national economies, in the process of their integration in the global financial and foreign exchange markets.

The conditions of the emerging foreign exchange market of Kazakhstan have specific features in the currency relations, particularly the specific practice of certain foreign exchange transactions. It is also necessary to compare the experience of the monetary system of Kazakhstan with the international practice and to formulate proposals to optimize the foreign exchange market as a whole, taking into account the significant changes in the global foreign exchange market.

Currently, only a few Kazakhstani banks propose using the system of margin trading, a unique opportunity to conduct foreign exchange operations on the FOREX market. With the increase in the resource base of banks in Kazakhstan, due to the high degree of currency risks in foreign exchange transactions on the Kazakhstan exchange market, it is necessary to establish a "limit" of currency transactions or the so-called capital adequacy ratio. In this case, the positive experience of the Bank of England can be used. Kazakhstan is particularly interested not only in the experience of the Bank of England's application of capital adequacy ratios, but also in the experience of the foreign exchange market regulation. For example, the London Code of Conduct, published by the British Bankers' Association under the auspices of the Bank of England, along with the instructions of the Central Bank, plays a significant role in the regulation of foreign exchange and other transactions in the foreign exchange market. This code was compiled by the Bank of England and the BBA (the British Bankers' Association) with active market dealers, brokers and other actors of the foreign exchange market. The basic principles established by the Code have to be known by all the actors of the foreign exchange market in the UK to ensure the most effective functioning of all segments of the market.

The main subjects of the global capital market are private businesses, states, and international financial institutions (the World Bank, the International Monetary Fund).

According to the procedure established in the Republic of Kazakhstan for Financial Reporting by regulatory agencies, the financial market consists of seven markets: the Cash, Credit, Deposit, Insurance, Pension, Foreign Exchange, and Securities markets (Iskakov, Bohaev, \& Ruzieva, 2005).

In Kazakhstan, a rather large number of transactions is conducted in the foreign exchange market. The actors who are involved in transactions in the foreign exchange market in Kazakhstan are the National Bank, commercial banks, firms, brokers, and households. For the National Bank, it is purchase and sale of foreign exchange, foreign exchange interventions. For commercial banks, it is foreign exchange buying/selling transactions for their customers, transactions to hedge foreign exchange risks. Firms conduct foreign trade activity and can also receive and provide loans in foreign exchange. Brokers act as intermediaries in foreign exchange and interest rate transactions. Households buy and sell foreign exchange.

The main factors that expectedly affect the migration of capital are:

1. The volume of transactions by resident banks; 
2. Net operations by exchange offices (Foreign exchange cash);

3. Imports/exports of foreign exchange cash by second-tier banks;

4. The trading volume on the Kazakhstan Stock Exchange

Figure 5 presents the data on the volume of transactions by resident banks from 2007 to 2013 (millions of currency units).

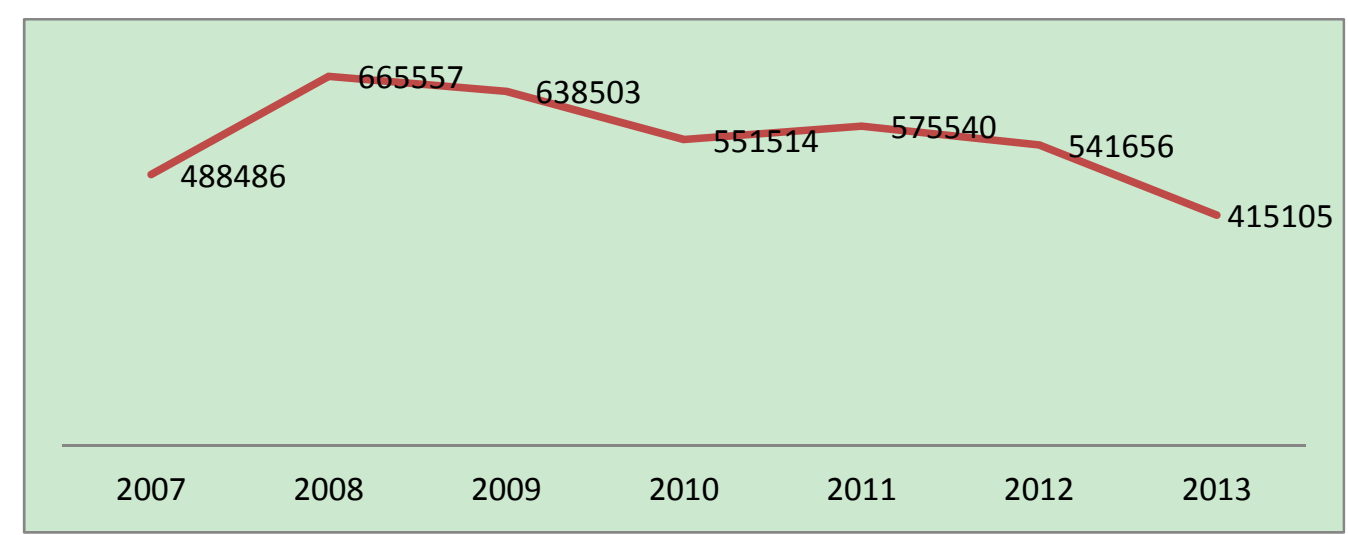

Figure 5. The volume of transactions by resident banks, according to (http://www.nationalbank.kz/)

Since 2008, a high value of transactions followed by a decrease in this indicator was observed. During this period, in addition to transactions committed by resident banks, the foreign exchange cash was also purchased and sold through exchange offices.

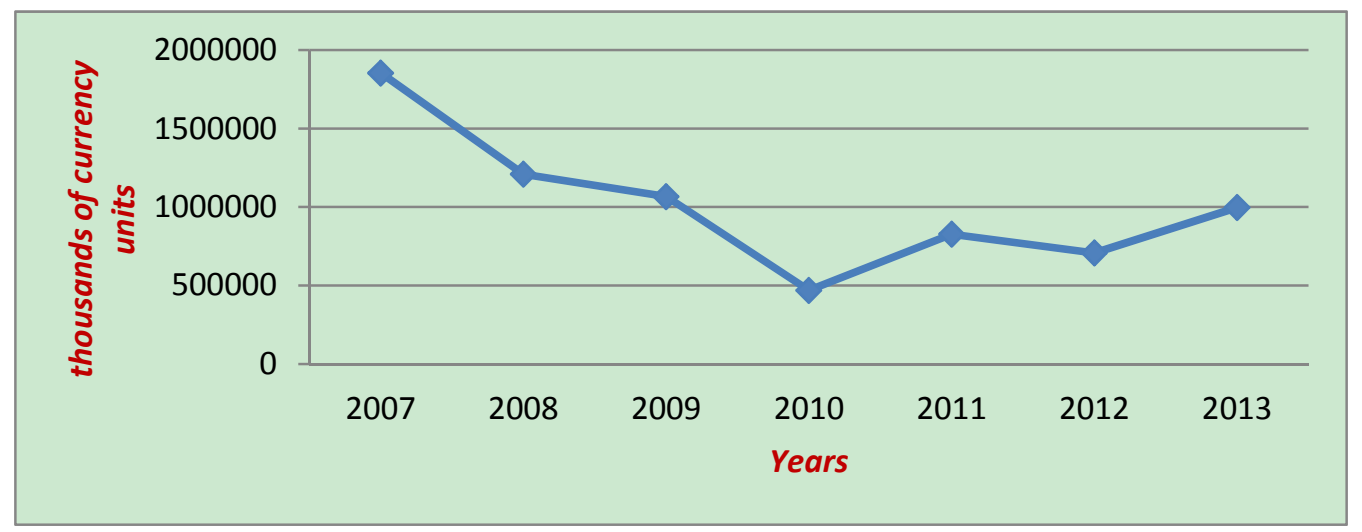

Figure 6. Net operations by exchange offices (foreign exchange cash), according to (http://www.nationalbank.kz/)

The following Figure 6 shows the number of net operations by foreign exchange offices, i.e. transactions with foreign exchange cash. The figure shows this indicator's decline in 2010. Analyzing the data on the presented figures, we can see the intentions to conduct transactions with foreign exchange cash in 2013. An increase in ruble transactions is especially obvious. Transactions with the foreign exchange cash of China and the UK appeared only in 2010. The possible factors of the capital migration in Kazakhstan are the imports/exports of currency by second-tier banks (Figure 7). The graph shows a decrease of transactions since 2007 and an increase in transactions since 2009. 


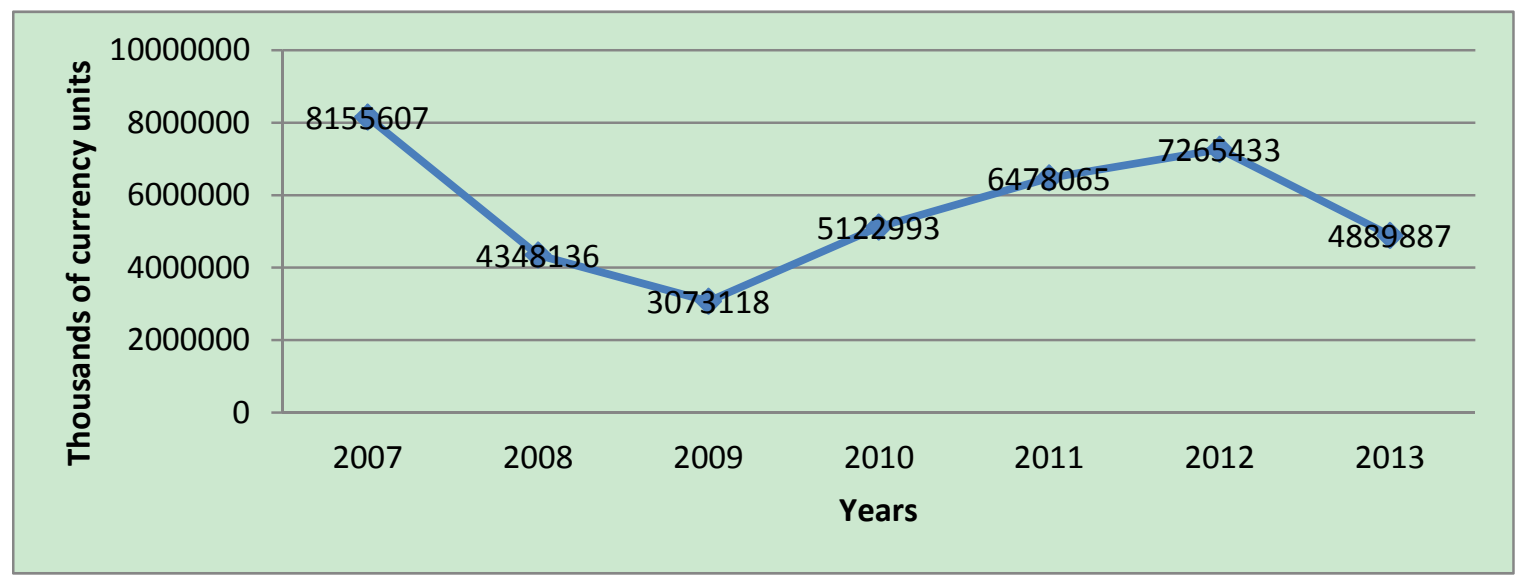

Figure 7. Imports/exports of foreign exchange cash by second-tier banks, according to (http://www.nationalbank.kz/)

One of the possible factors influencing on the capital migration may be the volume of foreign exchange trading on the Kazakhstan Stock Exchange. The data are provided in Figure 8.

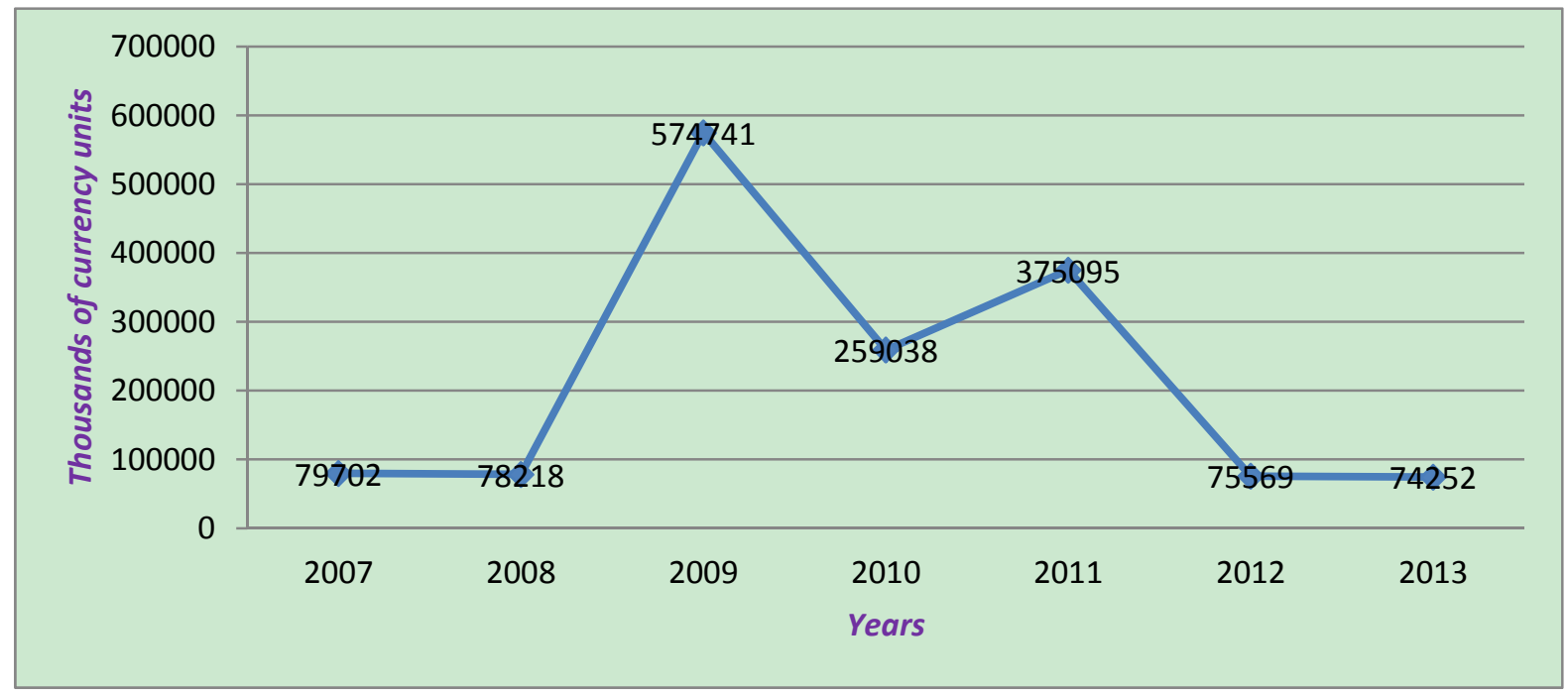

Figure 8. The volume of transactions at KASE, according to (http://www.nationalbank.kz/)

According to the provided data, an increase in trading volumes was observed in 2009. Further, there was a decrease in forex trading.

Considering the provided factors, we have the following data to find the coefficient of determination and the mathematical model.

Net capital imports/exports in Kazakhstan, in million US dollars: Y 1

The volume of transactions by resident banks: $\mathrm{X} 1$

Net operations by exchange offices (Foreign exchange cash): X 2

Imports/exports of foreign exchange cash by second-tier banks: X 3

The trading volume on the Kazakhstan Stock Exchange: X 4

\section{The Results}

The coefficient of determination is equal to 0.96 or $96 \%$, which shows a strong correlation of the above factors and the capital migration in Kazakhstan 
The model looks as follows:

$$
\mathrm{Y}=9067-0.02427 x_{1}+0.0053 x_{2}+0.0009 x_{3}-0.0026 x_{4}
$$

According to the obtained model, we can draw the following conclusions:

$-0.02427 x_{1}-$ it is the coefficient that shows the influence of the factor of the volume of transactions of resident banks within this model on the value of capital migration in Kazakhstan with the weight of -0.02427 . The minus mark indicates that this effect is negative, that is, the larger number of transactions by resident banks, the larger the capital outflow from the country is;

$+0.0053 x_{2}-$ it is the coefficient of influence of net operations by exchange offices (Foreign exchange cash) on the capital migration in Kazakhstan. According to the model, this effect is positive, which means that the more such deals, the larger the capital inflow is;

$+0.0009 x_{3}-$ it is the coefficient of imports/exports of foreign exchange cash by second-tier banks influence on the migration of capital in Kazakhstan. The influence in this case is directly proportional.

$0.0026 x_{4}-$ it is the coefficient that shows the weight of the influence of the factor of the trading volume at the Kazakhstan Stock Exchange on the rate of capital migration in Kazakhstan with the weight of -0.0026 . The minus mark indicates that this effect is negative, that is, the more trading, the larger the capital outflow from the country is.

The resulting coefficient of determination at $96 \%$ confirms the impact of money market instruments on the capital migration in Kazakhstan. Based on the calculated model, we can conclude on the strong interrelation between capital flows and indicators such as the volume of transactions by resident banks, net operation of exchange offices (Foreign exchange cash), import/export of foreign exchange cash by second-tier banks, trading volume on the Kazakhstan Stock Exchange.

In this situation, it is necessary to determine the importance of the monetary policy, the export incentives, as well as the protection of domestic manufacturers, control over the capital exports and imports, a combination of administrative and currency control in Kazakhstan.

\section{Discussion}

The imports of capital increased during the period under review, which was due to the activities of the non-banking sector of the economy of Kazakhstan. The growth of the direct investment outflow is caused by the reinvested earnings and the increase in debt instruments. The decrease in the inflow of direct investments is due to one-time large transactions of acquisition of a share in the capital of Kazakhstan. Devaluation of tenge in February 2014 also showcased the instability of the national currency.

The National Bank of Kazakhstan currently pays special attention to the process of strengthening the national banking system. In this connection, it seems appropriate to perform a more detailed study of the capital adequacy ratios used in the UK, as well as the experience in regulating the foreign exchange market with the Code of Conduct, which can be applied to the banking sector in Kazakhstan.

On the other hand, to increase public investment in the economy, it is necessary to tie the volume of foreign exchange reserves to one of the macroeconomic indicators, and transfer the excess foreign currency from the foreign exchange reserves of the National Bank to the state budget. The need for such measures is dictated by the task set by the Head of State on the development of the Investment Fund for the priority use of the financial resources of the country to develop the real economy, and also is due to the fact that the foreign exchange reserves of the National Bank amounted to slightly more than USD 28 billion at the end of November 2014, i.e. below the critical value of the Reddy Criterion.

In addition, there is a need to improve the efficiency of using the foreign exchange reserves of the country. While the National Bank allocates billions of resources abroad at low interest rates, the economic entities raise funds from other countries in the form of loans at higher interest rates.

As a result, the national economy every year loses hundreds of millions of dollars just by the difference in the percentage amount, and the losses are growing steadily. The solution to this problem could be a revision of the tax policy in terms of the overstatement of tax rates.

The foreign exchange funds of the National Fund and the reserves of the National Bank need to be used for lending to the domestic economy and lending for international settlements of the residents of the country, except for their return into the economic turnover and the subsequent impact on the rate of tenge. 
In this case, a stable growth in the circumstances of changes in the global environment will be ensured through the currency exchange rate.

It is necessary to develop a mechanism that would provide the necessary overall level of domestic prices with respect to the world prices, as well as broad implementation of advanced technology and equipment in the production of high-tech products by Kazakhstani producers.

Our country has not yet elaborated steps to use rationally the proceeds from the expected increase in oil exports, which may further be contributed to by further increase in foreign investment and continuing favorable global market conditions for energy and metals.

\section{Conclusion}

This article deals with the influence of financial instruments of the exchange market on the migration of capital in the Republic of Kazakhstan. To date, the majority of transactions are made in the foreign exchange market of Kazakhstan, which gives reason to make assumptions about the impact of the foreign exchange market on the flows of capital in Kazakhstan. The article provides statistical data for the period from 2007 to 2013, a regression analysis, conclusions, and recommendations. The resulting coefficient of determination at $96 \%$ confirms the impact of money market instruments on the capital migration in Kazakhstan. Also, this article contains the model of dependence of the presented factors on capital flows in Kazakhstan. Based on the calculated model, we can conclude on the strong interrelation between capital flows and indicators, such as the volume of transactions by resident banks, net operation of exchange offices (foreign exchange cash operations), imports/exports of foreign exchange cash by second-tier banks, trading volume on the Kazakhstan Stock Exchange. This study was conducted in the foreign exchange market of Kazakhstan. It is also necessary to study the securities market. Presumably, the lack of liquid financial instruments in the stock market of Kazakhstan also contributes to the capital outflow from the country.

\section{References}

Aizenman, J., Chinn, M., \& Ito, H. (2014). The Trilemma Indexes. Retrieved October 10, 2014, from http://web.pdx.edu/ ito/trilemma_indexes.htm

Al-Sakka, R., \& ap Gwilym, O. (2010). Split sovereign ratings and rating migrations in emerging economies. Emerging Markets Review, 11(2), 79-97. http://dx.doi.org/10.1016/j.ememar.2009.11.005

Bernshtam, B. E. (2013). "Capital flight" in the circumstances of globalization. Gorizonty, 5(10), 44-46.

Borishpolets, K., \& Chernyavskiy, S. (2012). The Common Economic Space of Russia, Belarus, and Kazakhstan. The Reality and Prospects. Central Asia and the Caucasus, 15(1), 142-152.

Brana,S., \& Lahet, D. (2010). Determinants of capital inflows into Asia: The relevance of contagion effects as push factors. Emerging Market Review, 11(3), 273-284. http://dx.doi.org/10.1016/j.ememar.2010.03.003

Cardoso, E. A., \& Dornbusch, R. (1989). Chapter 26 Foreign private capital flows. Handbook of Development Economics, 1387-1439. http://dx.doi.org/10.1016/S1573-4471(89)02013-9

Dobychin, E. V. (2003). Flight and repatriation of Russian capital (p. 161). Moscow: Plekhanov Russian Economic Academy.

Hayat, K. K., \& Jianqiu, Z. (2013). Common currency for Asia "now or never". Economic Modeling, 35, 170-174. http://dx.doi.org/10.1016/j.econmod.2013.06.045

Iskakov, U. M., \&Ruziyeva, E. A. (2014). Forming segments of the financial market at the present stage of Kazakhstan's economy development. World Applied Sciences Journal, 30(11), 1587-1592.

Iskakov, U. M., Bohaev, D. T., \& Ruzieva, E. A. (2005). Financial markets and intermediaries: Textbook (p. 295). Almaty: Ekonomika.

Kodongo, O., \& Ojah, K. (2013). Real exchange rates, trade balance and capital flows in Africa. Journal of Economics and Business, 66, 22-46. http://dx.doi.org/10.1016/j.jeconbus.2012.12.002

Kurmanalieva, E. S., \& Vinokourov, E. Yu. (2011). International capital flows in the CIS countries. ANO "Journal of the New Economic Association", 149, 192.

Levy Yeyati, E., Schmukler, S. L., \& Van Horen, N. (2009). International financial integration through the law of one price: The role of liquidity and capital controls. Journal of Financial Intermediation, 18(3), 432-463. http://dx.doi.org/10.1016/j.jfi.2008.09.004

Loskutov, V. I. (2000). Basic concepts of the modern economic theory. Study Guide. Murmansk: MSTU 
Publishing House.

Ostry, J. D., Ghosh, A. R., Chamon, M., \& Qureshi, M. S. (2012). Tools for managing financial-stability risks fromcapital inflows. Journal of International Economics, 88(2), 407-421. http://dx.doi.org/10.1016/j.jinteco. 2012.02.002

Plekhanov, D. A. (2009). Fluctuations in exchange rates. The dynamics of foreign exchange reserves and capital flow in Russia. Journal "Finance and Credit", Institute for Complex Strategic Studies (ICSS), 19, 50-55.

Richards, P. D., Myers, R. J., Swinton, S. M., \& Walker, R. T. (2012). Exchange rates soybean supply response, and deforestation in South America. Global Environmental Change, 22(2), 454-462. http://dx.doi.org/10. 1016/j.gloenvcha.2012.01.004

Sula, O., \& Wilett, Th. D. (2009). The reversibility of different types of capital flows to emerging markets. Emerging Markets Review, 10(4), 296-310. http://dx.doi.org/10.1016/j.ememar.2009.08.001

The National Bank of the Republic of Kazakhstan. (2015). The balance of payments and external debt of the Republic of Kazakhstan. Retrieved January 6, 2015, from http://www.nationalbank.kz/index.cfm?docid= $626 \&$ switch $=$ russian $\&$ CFID $=38672152 \&$ CFTOKEN $=29720504$

The National Bank of the Republic of Kazakhstan. The Statistical Bulletin for 2007-2013. Retrieved June 1, 2015, from http://www.nationalbank.kz/?docid=310\&switch=russian

Zapata, G. P. (2013). The migration-development nexus: Rendering migrants as transnational financial subjects through housing. Geoforum, 47, 93-102. http://dx.doi.org/10.1016/j.geoforum.2013.03.010

\section{Copyrights}

Copyright for this article is retained by the author(s), with first publication rights granted to the journal.

This is an open-access article distributed under the terms and conditions of the Creative Commons Attribution license (http://creativecommons.org/licenses/by/3.0/). 